\title{
Gingival Recession
}

National Cancer Institute

\section{Source}

National Cancer Institute. Gingival Recession. NCI Thesaurus. Code C82068.

A loss of gum tissue resulting in an exposure of the roots of the teeth. 